\title{
Effects of Grazing Intensity, Precipitation, and Temperature on Forage Production
}

\author{
Bob D. Patton, ${ }^{1}$ Xuejun Dong, ${ }^{1}$ Paul E. Nyren, ${ }^{2}$ and Anne Nyren ${ }^{3}$ \\ Authors are ${ }^{1}$ Assistant Range Scientist; ${ }^{2}$ Range Scientist and Director; and ${ }^{3}$ Administrative Officer, Central Grasslands Research Extension Center, \\ North Dakota State University, Streeter, ND 58483.
}

\begin{abstract}
Questions have been raised about whether herbaceous productivity declines linearly with grazing or whether low levels of grazing can increase productivity. This paper reports the response of forage production to cattle grazing on prairie dominated by Kentucky bluegrass (Poa pratensis L.) in south-central North Dakota through the growing season at 5 grazing intensities: no grazing, light grazing $\left(1.3 \pm 0.7\right.$ animal unit months $\left.[\mathrm{AUM}] \cdot \mathrm{ha}^{-1}\right)$, moderate grazing $\left(2.7 \pm 1.0 \mathrm{AUM} \cdot \mathrm{ha}^{-1}\right)$, heavy grazing $\left(4.4 \pm 1.2 \mathrm{AUM} \cdot \mathrm{ha}^{-1}\right)$, and extreme grazing $\left(6.9 \pm 2.1 \mathrm{AUM} \cdot \mathrm{ha}^{-1}\right.$; mean $\left.\pm \mathrm{SD}\right)$. Annual herbage production data were collected on silty and overflow range sites from 1989 to 2005. Precipitation and sod temperature were used as covariates in the analysis. On silty range sites, the light treatment produced the most herbage $\left(3410 \mathrm{~kg} \cdot \mathrm{ha}^{-1}\right)$, and production was reduced as the grazing intensity increased. Average total production for the season was $545 \mathrm{~kg} \cdot \mathrm{ha}^{-1}$ less on the ungrazed treatment and $909 \mathrm{~kg} \cdot \mathrm{ha}^{-1}$ less on the extreme treatment than on the light treatment. On overflow range sites, there were no significant differences between the light $\left(4131 \mathrm{~kg} \cdot \mathrm{ha}^{-1}\right)$, moderate $\left(4360 \mathrm{~kg} \cdot \mathrm{ha}^{-1}\right)$, and heavy treatments $\left(4362 \mathrm{~kg} \cdot \mathrm{ha}^{-1} ; P>0.05\right)$. Total production on overflow range sites interacted with precipitation, and production on the grazed treatments was greater than on the ungrazed treatment when precipitation (from the end of the growing season in the previous year to the end of the grazing season in the current year) was greater than 267.0, 248.4, 262.4, or $531.5 \mathrm{~mm}$ on the light, moderate, heavy, and extreme treatments, respectively. However, production on the extreme treatment was less than on the ungrazed treatment if precipitation was less than $315.2 \mathrm{~mm}$. We conclude that low to moderate levels of grazing can increase production over no grazing, but that the level of grazing that maximizes production depends upon the growing conditions of the current year.
\end{abstract}

\section{Resumen}

Han surgido preguntas acerca si la productividad herbácea disminuye linealmente con el apacentamiento, o si bajos niveles de apacentamiento pueden incrementarla. Este artículo reporta la respuesta de la producción de forraje al apacentamiento de ganado en praderas dominadas por "Kentucky bluegrass" (Poa pratensis L.) en la región centro-sur de North Dakota a través de la estación de crecimiento bajo cinco intensidades de apacentamiento: sin apacentamiento, ligera $\left(1.3 \pm 0.7 \mathrm{AUM} \cdot \mathrm{ha}^{-1}\right)$, moderada $\left(2.7 \pm 1.0 \mathrm{AUM} \cdot \mathrm{ha}^{-1}\right)$, fuerte $\left(4.4 \pm 1.2 \mathrm{AUM} \cdot \mathrm{ha}^{-1}\right)$ y extrema $\left(6.9 \pm 2.1 \mathrm{AUM} \cdot \mathrm{ha}^{-1}\right.$; media $\left.\pm \mathrm{DE}\right)$. Los datos de la producción anual de forraje se colectaron de 1989 al 2005 en sitios de pastizal de limo e inundables. La temperatura del macollo y la precipitación se usaron como covariables en el análisis estadístico. En los sitios de limo, el tratamiento de intensidad ligera produjo la mayor cantidad de forraje $\left(3410 \mathrm{~kg} \cdot \mathrm{ha}^{-1}\right)$ y la producción se redujo conforme la intensidad de apacentamiento incrementó. La producción total promedio para la estación fue $545 \mathrm{~kg} \cdot \mathrm{ha}{ }^{-1}$ menos en el tratamiento sin apacentamiento y $909 \mathrm{~kg} \cdot \mathrm{ha}^{-1}$ menos la intensidad extrema, en comparación con la intensidad ligera. En los sitios inundables no hubo diferencias significativas entre la intensidad ligera $\left(4131 \mathrm{~kg} \cdot \mathrm{ha}^{-1}\right)$, moderada $\left(4360 \mathrm{~kg} \cdot \mathrm{ha}^{-1}\right)$ y fuerte (4362 $\left.\mathrm{kg} \cdot \mathrm{ha}^{-1} ; \mathrm{P}>0.05\right)$. La producción total en estos sitios interactuó con la precipitación y la producción en los tratamientos de apacentamiento fue mayor que la del el tratamiento sin apacentamiento, cuando la precipitación (de final de la estación de crecimiento del año anterior a final de la estación de apacentamiento del año en curso) fue mayor a 267.0, 248.4, 262.4, o $531.5 \mathrm{~mm}$ en los tratamiento de intensidad ligera, moderada, fuerte y extrema, respectivamente. Sin embargo, la producción en la intensidad extrema fue menor que en el tratamiento sin apacentamiento, esto si la precipitación fue menor a $315.2 \mathrm{~mm}$. Concluimos que niveles de apacentamiento de ligero a moderado pueden incrementar la producción sobre el no apacentamiento, pero el nivel de apacentamiento que maximiza la producción depende de las condiciones de la estación crecimiento del año en curso.

Key Words: grasslands, grazing optimization hypothesis, grazing pressure, net primary production, northern mixed-grass prairie, stocking rate

\section{INTRODUCTION}

The grasses of the prairies have coevolved with large mammalian grazing herbivores since the Eocene Epoch, 45 to 55 million years

Correspondence: Bob Patton, Central Grasslands Research Extension Center, 4824 48th Ave SE, Streeter, ND 58483. Email: bob.patton@ndsu.edu

Manuscript received 25 January 2007; manuscript accepted 21 August 2007. ago (Stebbins 1981). Herbivores can shape the structure and dynamics of the community and act as agents of natural selection in the evolution of plants (Jefferies 1988). However, the possibility that herbivory could have a beneficial effect on a grazed plant is a highly debated topic (Belsky 1986; McNaughton 1993; Painter and Belsky 1993; Biondini et al. 1998).

Questions about proper stocking rate and the effect of livestock grazing on long-term forage productivity are basic to 
range management (Walker 1995). Answering these questions is complicated by the effects that variations in weather, primarily precipitation and temperature, have on forage production (Smoliak 1986; Sala et al. 1988; Lauenroth and Sala 1992).

The water available for plant growth is stored in the upper layers of the soil. For the current year's crop, this water includes precipitation stored since the end of the previous year's growing season. Most studies that have used the concept of "crop year" precipitation (e.g., Angell et al. 1990; Ganskopp 1998) have used a fixed date, e.g., 1 September or 1 October, as the beginning of the crop year, even though the end of the growing season can vary considerably from year to year, especially in the northern Great Plains. Few studies have applied the concept of "crop year" precipitation to grassland production.

Although plant growth cannot occur below $0^{\circ} \mathrm{C}$, most studies have found either no relationship between temperature and production (Sala et al. 1988; Laurenroth and Sala 1992) or a negative correlation between these factors (Smoliak 1986), although plant morphological development is primarily controlled by temperature (Frank and Ries 1990). Wang (1960) suggests that the height at which temperature is measured should vary with the height of the plants. For prairie vegetation, the temperature at or just below the soil surface probably has the strongest relationship to plant growth.

Long-term data sets, covering a span of wet to dry years, can address questions concerning time-lag effects. While production of individual tillers may be closely related to the current year's precipitation, a dry year, or a series of dry years, may reduce basal cover, thereby constraining production in subsequent years even when conditions are favorable for growth (Milchunas et al. 1994). Despite the numerous quantitative reports concerning the effects of grazing domesticated livestock on rangeland in the northern Great Plains, most studies have been short term ( 2 to 5 years) or lacking the detail needed to make meaningful comparisons between studies.

This study looks at the effect of five intensities of grazing on the long-term productivity of the grassland and examines how productivity is influenced by crop-year precipitation and growing degree-days. We hypothesized that forage production would be greatest at some intermediate level of grazing, but that it would vary with precipitation and temperature.

\section{METHODS}

\section{Study Site}

The study was conducted at the Central Grasslands Research Extension Center, located on the Missouri Coteau, $12 \mathrm{~km}$ northwest of Streeter in south-central North Dakota, lat $46^{\circ} 46^{\prime} \mathrm{N}$, long $99^{\circ} 28^{\prime} \mathrm{W}$. The study site is typical of rangeland in the Missouri Coteau. This rangeland consists of a mosaic of soil types and range sites and is dominated by silty range sites (nearly level to rolling uplands, with slopes from 1\% to $15 \%$ and deep, moderately well-drained to moderately fine-textured soils in the Barnes, Svea, Wenshaw, and Buse series) and overflow range sites (nearly level to gently sloping lands that receive runoff water from higher sloping lands, with deep, well-aerated sandy loam to clay-textured soils in the Svea, Svea-Gardena, Hamerly,
Tonka, and Barnes series). The elevation of the study site is about $587 \mathrm{~m}$. This area has a continental climate, with an average January temperature of $-16^{\circ} \mathrm{C}$ and an average August temperature of $20^{\circ} \mathrm{C}$. On average, there are 131 frost-free days per year. Mean annual precipitation is $454 \mathrm{~mm}$, with about $72 \%$ of the precipitation occurring during the growing months from May to September. The original vegetation was mixed-grass prairie. Most of it was plowed by homesteaders and then allowed to go back to grass during the droughts of the 1950s. Before the current study began, the area was moderately grazed by livestock and wildlife. Silty sites are dominated by Kentucky bluegrass (Poa pratensis L.), green needlegrass (Nassella viridula [Trin.] Barkworth), sun sedge (Carex inops Bailey subsp. heliophila [Mackenzie] Crins), and western wheatgrass (Pascopyrum smithii [Rydb.] A. Löve). Overflow sites are dominated by Kentucky bluegrass, smooth brome (Bromus inermis Leyss.), western snowberry (Symphoricarpos occidentalis Hook.), and stiff goldenrod (Oligoneuron rigidum [L.] Small var. humile [Porter] Nesom; nomenclature follows USDA, NRCS 2006). The balance of the vegetation is composed of a very diverse assemblage of grasses and forbs, most of which are readily grazed by livestock. Kentucky bluegrass and smooth brome are introduced invasive species that have come to dominate the grasslands in much of this region.

\section{Treatments}

A $1.54-\mathrm{km}^{2}$ area was divided into 12 pastures of nearly equal carrying capacity. Each pasture was stocked with cattle to achieve one of four different grazing intensities: light, moderate, heavy, or extreme. Each intensity was replicated on three different pastures. A fifth treatment (no-grazing) was established using six $10 \times 120 \mathrm{~m}$ exclosures, three on silty sites and three on overflow sites. Light treatment left $65 \%$ of forage produced in an "average year" remaining at the end of the grazing season, moderate treatment left $50 \%$, heavy treatment left $35 \%$, and extreme treatment left $20 \%$. Livestock entry and removal dates were adjusted yearly relative to precipitation and plant phenology conditions to keep utilized forage within the desired level for each treatment. During the study period (1989-2005), the length of the grazing season ranged from 55 days in 2002 to 181 days in 1990 . The pastures were stocked too lightly during the first two years of the study because the production potential of the sites was not well defined. From 1991 to 2005 the mean stocking density \pm the standard deviation was $1.3 \pm 0.7$ animal unit months (AUM) $\cdot \mathrm{ha}^{-1}$ on the light grazing treatment, $2.7 \pm 1.0 \mathrm{AUM} \cdot \mathrm{ha}^{-1}$ on the moderate grazing treatment, $4.4 \pm 1.2 \mathrm{AUM} \cdot \mathrm{ha}^{-1}$ on the heavy grazing treatment, and $6.9 \pm 2.1 \mathrm{AUM} \cdot \mathrm{ha}^{-1}$ on the extreme grazing treatment. Each pasture contained both silty and overflow range sites, and monitoring locations were selected on both types of range sites in each pasture.

\section{Data Collection}

Forage production and utilization were determined using the cage comparison method (Cook and Stubbendieck 1986). At the beginning of each grazing season, five $0.25-\mathrm{m}^{2}$ plots were caged. Two uncaged plots were paired with each caged plot on each monitoring site (15 total plots per monitoring site). For each set of three plots (one caged and two uncaged), one of the 
Table 1. Variables used as covariates in analysis of forage production on silty and overflow range sites at the Central Grassland Research Extension Center.

Beginning of the grazing season

P2B The sum of precipitation $(\mathrm{cm})$ from the end of the growing season in the previous year to the beginning of the grazing season in the current year.

T2B The sum of mean daily sod temperature $\left({ }^{\circ} \mathrm{C}\right)$ above $0^{\circ} \mathrm{C}$ from when the ground thawed until the beginning of the grazing season in the current year.

Middle of the growing season

P2M The sum of precipitation $(\mathrm{cm})$ from the end of the growing season in the previous year to the peak of the growing season in the current year.

T2M The sum of mean daily sod temperature $\left({ }^{\circ} \mathrm{C}\right)$ above $0^{\circ} \mathrm{C}$ from when the ground thawed until the peak of the growing season in the current year.

End of the grazing season

P2E The sum of precipitation $(\mathrm{cm})$ from the end of the growing season in the previous year to the end of the grazing season in the current year.

T2E The sum of mean daily sod temperature $\left({ }^{\circ} \mathrm{C}\right.$ ) above $0^{\circ} \mathrm{C}$ from when the ground thawed until the end of the grazing season in the current year.

uncaged plots was clipped before grazing. A mid-grazing season sample was taken at the peak of forage production for the year. The peak was determined by observing that the vegetation was beginning to dry, usually in mid-July. At that time, two new plots were chosen to match each of the original uncaged plots as nearly as possible in amount and species of grasses, forbs, and shrubs, and the original plots were clipped. One of each pair of new plots was caged, and at the end of the grazing period, the herbage from each remaining plot was clipped. Only the current year's growth was retained, and herbage was separated into three groups (shrubs, forbs, and grasses) on overflow sites, and into two groups (forbs and grasses) on silty sites (with occasional shrubs being placed with forbs). Samples were oven-dried at $66^{\circ} \mathrm{C}$ for $48 \mathrm{~h}$ and weighed to determine the amount of herbaceous production and percent utilization of the forage. Herbage clipped from inside caged plots at the peak of the growing season provided an estimate of peak production $\left(P_{b}\right)$. Growth $(G)$ (or disappearance) from peak $(p)$ to the end $(e)$ of the grazing season is

$$
G_{p e}=H_{i e}-H_{o p}
$$

where $H_{i e}=$ herbage from inside cages at the end of the grazing season and $H_{o p}=$ herbage from outside cages at the peak of the season. End of grazing season production was $P_{b}+G_{p e}$.

Daily precipitation was recorded at the study site during the growing season and at the National Weather Service Cooperative Weather Observation Site located $\sim 3 \mathrm{~km}$ south of the study site during the dormant season. Daily mean sod temperature was recorded under turf at a $100 \mathrm{~mm}$ depth from the NDAWN (Enz 2006) weather station located approximately $8 \mathrm{~km}$ southeast of the study site.

\section{Data Summary and Analyses}

Through phenological observations of the dominant plant species from 1988 through 1997, it was determined that the

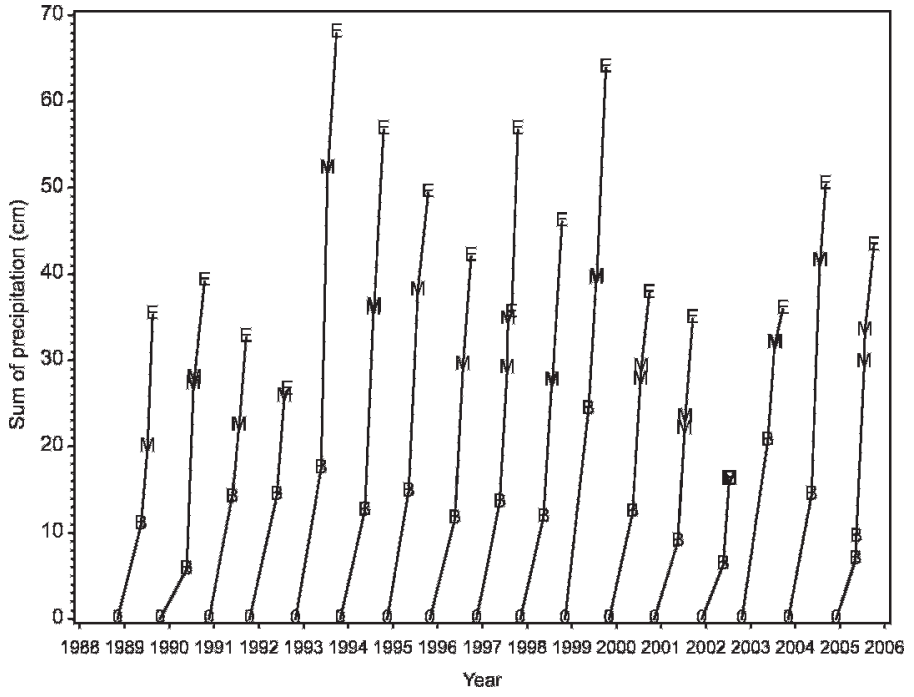

Figure 1. Sum of precipitation from the end of the growing season the previous year until production was sampled. $0=$ Date growth stopped for year. $B=$ Beginning of grazing season production sampling. $M=$ Middle of grazing season production sampling. $E=$ End of grazing season production sampling. Sampling on the silty range sites preceded sampling on the overflow range sites by 0 to 9 days.

end of the growing season occurs when the ground surface freezes or is covered with snow, and the beginning of the growing season occurs when the ground surface thaws. Precipitation was totaled from the end of the previous year's growing season to the date of production sampling for each of the three sampling periods. Daily mean sod temperatures were summed from when the ground thawed in the spring until the date of production sampling for each sampling period. These measures allowed us to relate production to both crop-year precipitation, and growing degree-days with a base temperature of $0^{\circ} \mathrm{C}$ (Wang 1960; Frank and Ries 1990).

Data were analyzed using analysis of covariance, with forage production as the dependent variable and grazing treatment as the independent variable. Precipitation and sod temperature were used as covariates, with variables defined as shown in Table 1 (Figs. 1 and 2). Analysis of covariance followed the methods of Huitema (1980). Results were considered significant at the $P=0.05$ level.

\section{RESULTS}

For all measures of biomass, there was a significant difference in production between the range sites and an interaction between range site and grazing intensity. On silty range sites, the light treatment produced the most herbage, and production was reduced as the grazing intensity increased. Average total production for the season was also less on the ungrazed treatment. On overflow range sites, the heavy treatment tended to be the most productive, but there were no significant differences between the light, moderate, and heavy treatments. Total production on overflow range sites interacted with precipitation, and production on the grazed treatment was greater than on the ungrazed treatment when precipitation (from the end of the growing season in the previous year to the 


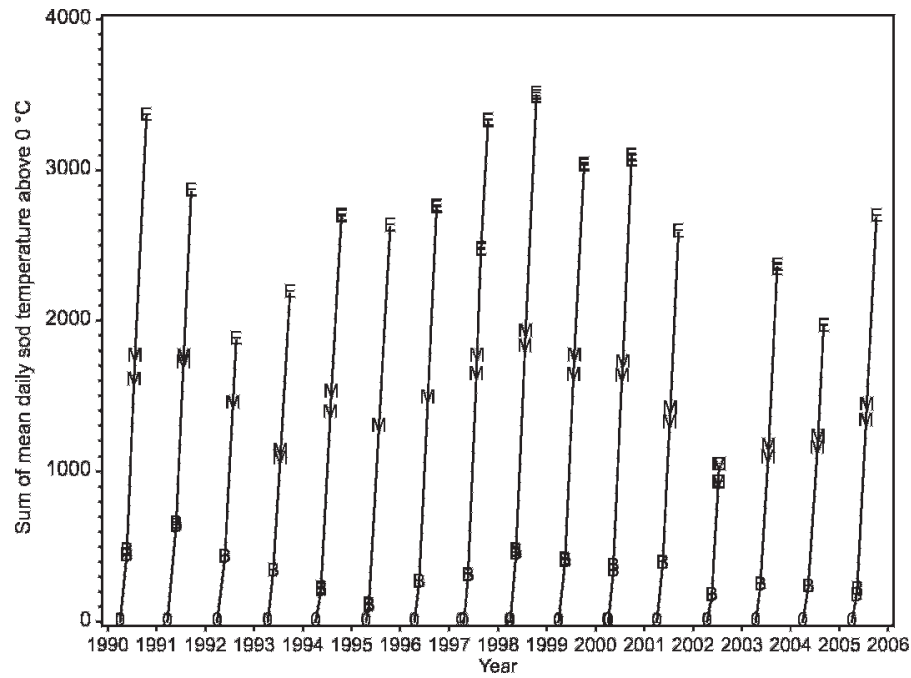

Figure 2. Sum of mean daily sod temperature above $0^{\circ} \mathrm{C}$ from when the ground thawed until production was sampled. $0=$ Date ground thawed for year; $B=$ Beginning of grazing season production sampling; $\mathrm{M}=$ Middle of grazing season production sampling; $\mathrm{E}=$ End of grazing season production sampling. Sampling on the silty range sites preceded sampling on the overflow range sites by 0 to 9 days.

end of the grazing season in the current year) reached a specific level on each treatment. However, production on the extreme treatment was less than on the ungrazed treatment if precipitation was less than $31.52 \mathrm{~cm}$. Results for each range site will be presented separately by sampling period of the grazing season and herbage type.

\section{Production at Beginning of Grazing Season}

Grass Production. For grass production at the beginning of the grazing season, the effects of grazing intensity (GI), range site, $\mathrm{P} 2 \mathrm{~B}$ (defined as the sum of precipitation from the end of the growing season in the previous year to the beginning of the grazing season in the current year; see Table 1), T2B (defined as the sum of mean daily sod temperature above $0^{\circ} \mathrm{C}$ from when the ground thawed until the beginning of the grazing season in the current year), and their interactions were all significant $(P<0.05)$.

Overflow Range Sites. For the overflow range sites, the P2B by GI interaction was not significant $(P=0.6240)$. Grass production on all grazing intensities responded similarly with respect to precipitation. The T2B by GI interaction was significant $\left(P<0.0001, R^{2}=0.35\right)$; the slope of the temperature response varied by grazing intensity (Fig. 3 ). Slopes of the temperature response were $2.05 \mathrm{~kg} \cdot \mathrm{ha}^{-1} \cdot{ }^{\circ} \mathrm{C}^{-1}\left(R^{2}=0.48\right)$ for the extreme grazing treatment and $0.99 \mathrm{~kg} \cdot \mathrm{ha}^{-1} \cdot{ }^{\circ} \mathrm{C}^{-1}$ $\left(R^{2}=0.26\right)$ for the ungrazed treatment, but the slopes for the other treatments were not significantly different from zero: $-0.08 \mathrm{~kg} \cdot \mathrm{ha}^{-1} \cdot{ }^{\circ} \mathrm{C}^{-1}\left(R^{2}=0.09\right)$ for the heavy treatment, $0.23 \mathrm{~kg} \cdot \mathrm{ha}^{-1} \cdot{ }^{\circ} \mathrm{C}^{-1}\left(R^{2}=0.24\right)$ for the moderate treatment, and $0.08 \mathrm{~kg} \cdot \mathrm{ha}^{-1} \cdot{ }^{\circ} \mathrm{C}^{-1}\left(R^{2}=0.14\right)$ for the light treatment. The slope for the extreme grazing treatment was significantly greater than the slope for all the other treatments. The slope for the ungrazed treatment was significantly greater than the slope for the heavy treatment, but the other grazing treatments were not significantly different from one another (Fig. 3). Aside from

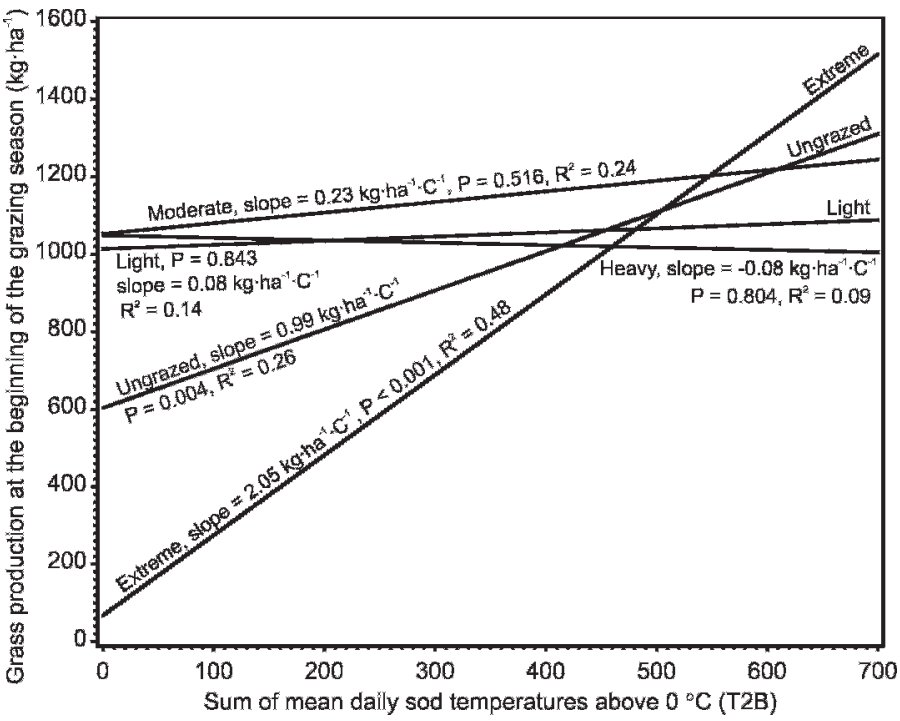

Figure 3. Overflow range site relationship between grass production at the beginning of the grazing season and T2B from 1989 to 2005.

the extreme grazing treatment, the effect of $\mathrm{T} 2 \mathrm{~B}$ on grass production was not significant $(P=0.086)$.

Grass production at the beginning of the grazing season on the ungrazed, light, moderate, and heavy treatments on overflow range sites increased $30.16 \mathrm{~kg} \cdot \mathrm{ha}^{-1} \cdot \mathrm{cm}^{-1}$ of P2B. Generally, moderate grazing was most productive and extreme grazing was least productive depending on the effect of temperature (Table 2; Fig. 3).

Silty Range Sites. For the silty range sites, the T2B by GI interaction was not significant. Grass production on all treatments responded similarly with respect to temperature, increasing about $1.61 \mathrm{~kg} \cdot \mathrm{ha}^{-1} \cdot{ }^{\circ} \mathrm{C}^{-1}$. The P2B by GI interaction was significant $\left(P=0.0036, R^{2}=0.61\right)$. The slope of the precipitation response was different for each grazing intensity (Fig. 4). The slopes of the precipitation response were not significantly different from zero for extreme, heavy, or moderate treatments, but grass growth increased $32.48 \mathrm{~kg} \cdot \mathrm{ha}^{-1} \cdot \mathrm{cm}^{-1}\left(R^{2}=0.29\right)$ of P2B on the light treatment and $46.31 \mathrm{~kg} \cdot \mathrm{ha}^{-1} \cdot \mathrm{cm}^{-1}\left(R^{2}=0.58\right)$ of $\mathrm{P} 2 \mathrm{~B}$ on the ungrazed treatment.

The light and ungrazed treatments were the most productive treatments. Production decreased as grazing intensity increased, but the ungrazed treatment was not significantly different from the heavy treatment if $\mathrm{P} 2 \mathrm{~B}$ was less than $7 \mathrm{~cm}$, and it was not significantly greater than the moderate treatment if $\mathrm{P} 2 \mathrm{~B}$ was less than $12 \mathrm{~cm}$ (Table 3; Fig. 4).

Forb Production. Overflow Range Sites. For forbs, the interactions of $\mathrm{P} 2 \mathrm{~B}$ and $\mathrm{T} 2 \mathrm{~B}$ with GI were not significant. On overflow sites, P2B significantly increased forb production by $8.02 \mathrm{~kg} \cdot \mathrm{ha}^{-1} \cdot \mathrm{cm}^{-1}$, and T2B significantly increased forb production by $0.19 \mathrm{~kg} \cdot \mathrm{ha}^{-1} \cdot{ }^{\circ} \mathrm{C}^{-1}$. Forb production was greatest on the extremely grazed treatment and decreased as grazing intensity decreased (Table 2 ).

Silty Range Sites. On silty range sites, T2B did not significantly affect forb production, but P2B increased forb production by $9.60 \mathrm{~kg} \cdot \mathrm{ha}^{-1} \cdot \mathrm{cm}^{-1}$ of precipitation. Forb production did not differ between extreme, heavy, or moderate 
Table 2. Mean grass, forb, shrub, and total production on overflow range sites at the beginning of the grazing season from 1989 to 2005 . Grass production means are adjusted for the effect of $\mathrm{P} 2 \mathrm{~B}$, shrub production means are adjusted for the effect of T2B, and forb and total production means are adjusted for the effects of P2B and T2B.

\begin{tabular}{|c|c|c|c|c|c|c|c|}
\hline \multirow[b]{2}{*}{$\begin{array}{l}\text { Grazing } \\
\text { treatment }\end{array}$} & \multicolumn{2}{|c|}{ Grass production } & \multirow[b]{2}{*}{$\begin{array}{l}\text { Forb production } \\
\left(\mathrm{kg} \cdot \mathrm{ha}^{-1}\right)\end{array}$} & \multirow[b]{2}{*}{$\begin{array}{l}\text { Shrub production } \\
\left(\mathrm{kg} \cdot \mathrm{ha}^{-1}\right)\end{array}$} & \multicolumn{3}{|c|}{ Total production } \\
\hline & $\begin{array}{c}\text { Grass } \\
\text { production } \\
\left(\mathrm{kg} \cdot \mathrm{ha}^{-1}\right)\end{array}$ & $\begin{array}{c}\text { Greater than } \\
\text { extreme if } \\
{\mathrm{T} 2 \mathrm{~B}^{1}}^{1}\end{array}$ & & & $\begin{array}{l}\text { Total production } \\
\left(\mathrm{kg} \cdot \mathrm{ha}^{-1}\right)\end{array}$ & $\begin{array}{c}\text { Greater than } \\
\text { extreme if } \\
{\mathrm{T} 2 \mathrm{~B}^{3}}^{3}\end{array}$ & $\begin{array}{c}\text { Less than } \\
\text { extreme } \\
\text { if } \mathrm{T}^{2} \mathrm{~B}^{4}\end{array}$ \\
\hline Ungrazed & $920 b^{5,6}$ & $<379$ & $115 d$ & $124 \mathrm{a}$ & $1194 \mathrm{~b}$ & $<293$ & - \\
\hline Light & $1017 a b$ & $<401$ & $136 \mathrm{~cd}$ & $64 \mathrm{~cd}$ & $1273 b$ & $<340$ & $>556$ \\
\hline Moderate & $1095 \mathrm{a}$ & $<446$ & $180 \mathrm{c}$ & 77 bc & $1428 \mathrm{a}$ & $>424$ & - \\
\hline Heavy & $998 a b^{7}$ & $<392$ & $227 \mathrm{~b}$ & $106 a b$ & $1402 a^{8}$ & $<394$ & $>597$ \\
\hline Extreme & - & - & $282 \mathrm{a}$ & $41 \mathrm{~d}$ & - & - & - \\
\hline Pooled SE & 47 & & 16 & 12 & 46 & & \\
\hline
\end{tabular}

${ }^{1}$ Production was greater on the treatment than on the extreme grazing treatment if T2B was less than the given value; otherwise, they were not significantly different $(P=0.05)$.

${ }^{2}$ Because grass, forb, shrub, and total are each adjusted separately for the effects of P2B and/or T2B, grass, forb, and shrub production do not sum to total production.

${ }^{3}$ Production was greater on the treatment than on the extreme grazing treatment if T2B was less than the given value; otherwise, they were not significantly different $(P=0.05)$.

${ }^{4}$ Production was less on the treatment than on the extreme grazing treatment if T2B was greater than the given value; otherwise, they were not significantly different $(P=0.05)$.

${ }^{5}$ Means followed by the same letter in the same column are not significantly different at the $P \leq 0.05$ level.

${ }^{6}$ Grass production on ungrazed was significantly less than heavy if T2B was less than 299; otherwise, they were not significantly different.

${ }^{7}$ Grass production was greater on the extreme grazing treatment than on heavy if T2B was greater than $596(P=0.05)$.

${ }^{8}$ Total production on heavy was significantly greater than ungrazed if T2B was less than 381 ; otherwise, they were not significantly different.

treatments, but forb production was significantly greater on these treatments than on the ungrazed or light treatments (Table 3).

Shrub Production. Overflow Range Sites. For shrub production on overflow range sites, neither P2B nor the interactions of P2B or T2B with GI were significant. However, shrub production increased $0.19 \mathrm{~kg} \cdot \mathrm{ha}^{-1} \cdot{ }^{\circ} \mathrm{C}^{-1}$ of $\mathrm{T} 2 \mathrm{~B}$. The ungrazed treatment had greater shrub production than the extreme treatment, but production did not decrease linearly with grazing intensity (Table 2).

Total Production. Silty Range Sites. The interaction of P2B and GI was not significant for total production at the beginning of the grazing season, nor was the interaction of T2B and GI significant on silty range sites. Total production on silty range sites increased $24.02 \mathrm{~kg} \cdot \mathrm{ha}^{-1} \cdot \mathrm{cm}^{-1}$ of P2B and

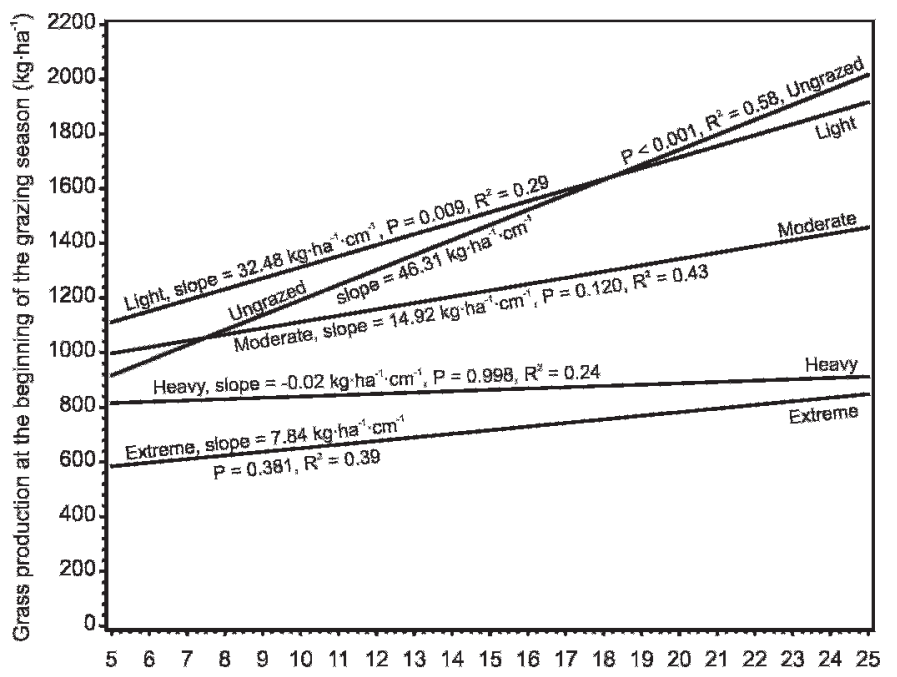
Sum of precipitation (cm) from the end of the growing season the previous year (P2B)

Figure 4. Silty range site relationship between grass production at the beginning of the grazing season and P2B from 1989 to 2005.
$1.69 \mathrm{~kg} \cdot \mathrm{ha}^{-1} \cdot{ }^{\circ} \mathrm{C}^{-1}$ of T2B. Production was greatest on the light and ungrazed treatments and then decreased with increased grazing intensity (Table 3).

Overflow Range Sites. On the overflow range sites, the T2B by GI interaction was significant $\left(P<0.001, R^{2}=0.46\right)$. Slopes of the temperature response were $2.81 \mathrm{~kg} \cdot \mathrm{ha}^{-1} \cdot{ }^{\circ} \mathrm{C}^{-1}$ $\left(R^{2}=0.60\right)$ on the extreme treatment, $0.61 \mathrm{~kg} \cdot \mathrm{ha}^{-1} \cdot{ }^{\circ} \mathrm{C}^{-1}$ $\left(R^{2}=0.17\right)$ on the heavy treatment, $1.11 \mathrm{~kg} \cdot \mathrm{ha}^{-1} \cdot{ }^{\circ} \mathrm{C}^{-1}$ $\left(R^{2}=0.45\right)$ on the moderate treatment, $0.83 \mathrm{~kg} \cdot \mathrm{ha}^{-1} \cdot{ }^{\circ} \mathrm{C}^{-1}$ $\left(R^{2}=0.23\right)$ on the light treatment, and $1.74 \mathrm{~kg} \cdot \mathrm{ha}^{-1} \cdot{ }^{\circ} \mathrm{C}^{-1}$ $\left(R^{2}=0.42\right)$ on the ungrazed treatment. The slope on the extreme treatment was greater than on any other treatment (Fig. 5). The heavy treatment had the weakest response to temperature, but it was only significantly less than on the ungrazed and extreme treatments. Without the extreme treatment, the slopes of the treatments were $29.58 \mathrm{~kg} \cdot \mathrm{ha}^{-1} \cdot \mathrm{cm}^{-1}$ of $\mathrm{P} 2 \mathrm{~B}$ and $1.07 \mathrm{~kg} \cdot \mathrm{ha}^{-1} \cdot{ }^{\circ} \mathrm{C}^{-1}$ of T2B. Generally, the moderate and heavy treatments produced

Table 3. Mean grass, forb, and total production on silty range sites at the beginning of the grazing season from 1989 to 2005. Grass and total production are adjusted for the effects of $\mathrm{P} 2 \mathrm{~B}$ and $\mathrm{T} 2 \mathrm{~B}$, and forb production is adjusted for the effect of $\mathrm{P} 2 \mathrm{~B}$.

\begin{tabular}{lccc}
\hline $\begin{array}{c}\text { Grazing } \\
\text { treatment }\end{array}$ & $\begin{array}{c}\text { Grass production } \\
\left(\mathrm{kg} \cdot \mathrm{ha}^{-1}\right)\end{array}$ & $\begin{array}{c}\text { Forb production } \\
\left(\mathrm{kg} \cdot \mathrm{ha}^{-1}\right)\end{array}$ & $\begin{array}{c}\text { Total production } \\
\left(\mathrm{kg} \cdot \mathrm{ha}^{-1}\right)\end{array}$ \\
\hline Ungrazed & $1383 \mathrm{a}^{2,3}$ & $76 \mathrm{~b}$ & $1469 \mathrm{ab}$ \\
Light & $1478 \mathrm{a}$ & $59 \mathrm{~b}$ & $1546 \mathrm{a}$ \\
Moderate & $1208 \mathrm{~b}$ & $140 \mathrm{a}$ & $1371 \mathrm{~b}$ \\
Heavy & $868 \mathrm{c}$ & $155 \mathrm{a}$ & $1048 \mathrm{C}$ \\
Extreme & $693 \mathrm{~d}$ & $159 \mathrm{a}$ & $875 \mathrm{~d}$ \\
Pooled SE & 48 & 11 & 48 \\
\hline
\end{tabular}

${ }^{1}$ Because grass, forb, and total are each adjusted separately for the effects of P2B and T2B, grass and forb production do not sum to total production.

${ }^{2}$ Means followed by the same letter in the same column are not significantly different at the $P \leq 0.05$ level.

${ }^{3}$ Grass production on ungrazed was significantly greater than on heavy if P2B was greater than $7 \mathrm{~cm}$ and significantly greater than on moderate if $\mathrm{P} 2 \mathrm{~B}$ was greater than $12 \mathrm{~cm}$; otherwise, they were not significantly different. 


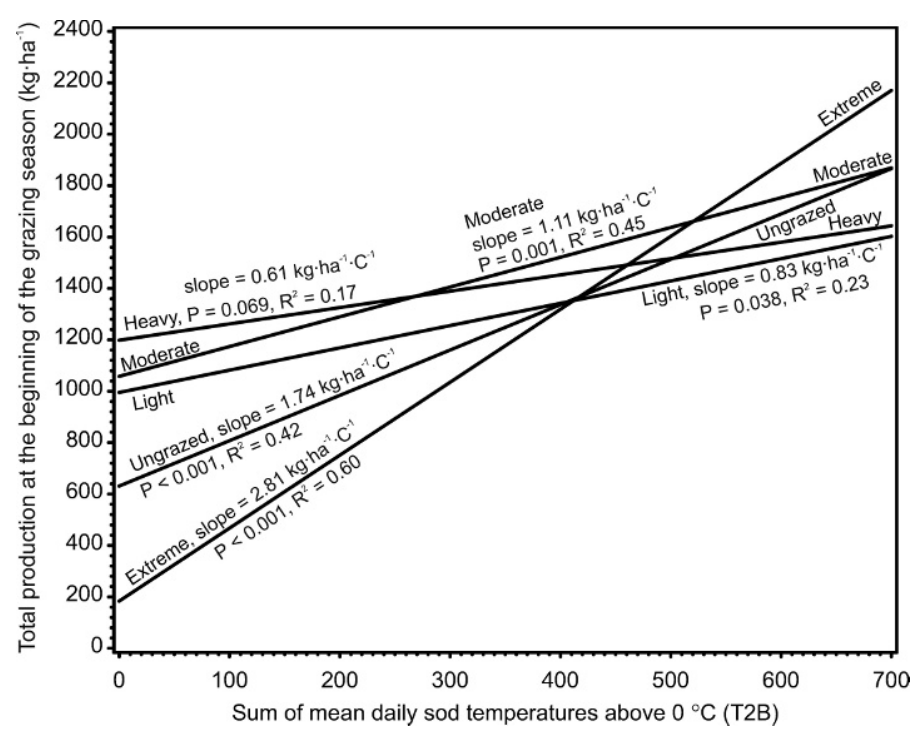

Figure 5. Overflow range site relationship between total production at the beginning of the grazing season and T2B from 1989 to 2005.

the most forage at the beginning of the grazing season, with production declining at lower and higher grazing intensities depending on spring sod temperatures (Table 2).

\section{Production at Middle of Grazing Season}

Grass Production. Overflow Range Sites. On overflow range sites, the mid-grazing season grass production was significantly affected by GI, P2M (defined as the sum of precipitation from the end of the growing season in the previous year to the peak of the growing season in the current year), and T2M (defined as the sum of mean daily sod temperature above $0^{\circ} \mathrm{C}$ from when the ground thawed until the peak of the growing season in the current year). However, the interactions of temperature and precipitation with grazing intensity were not significant. P2M increased grass production $31.93 \mathrm{~kg} \cdot \mathrm{ha}^{-1} \cdot \mathrm{cm}^{-1}$ and T2M increased grass production $0.61 \mathrm{~kg} \cdot \mathrm{ha}^{-1} \cdot{ }^{\circ} \mathrm{C}^{-1}$. The extreme treatment produced significantly less grass than all the other treatments, but the other treatments did not differ significantly (Table 4).

Silty Range Sites. On silty range sites, the mid-grazing season grass production was significantly affected by GI, P2M, and T2M. $\mathrm{P} 2 \mathrm{M}$ increased grass production by $18.92 \mathrm{~kg} \cdot \mathrm{ha}^{-1} \cdot \mathrm{cm}^{-1}$ and $\mathrm{T} 2 \mathrm{M}$ increased grass production by $1.06 \mathrm{~kg} \cdot \mathrm{ha}^{-1} \cdot{ }^{\circ} \mathrm{C}^{-1}$. The light treatment produced the most grass. The ungrazed and moderate treatments produced significantly less grass than the light treatment but more than the heavy and extreme treatments (Table 5).

Forb Production. The midseason forb production was closely related to $\mathrm{P} 2 \mathrm{M}$ and $\mathrm{T} 2 \mathrm{M}$. However, the interactions of $\mathrm{P} 2 \mathrm{M}$ and T2M with GI were not significant on either the overflow or silty range sites.

Overflow Range Sites. On overflow range sites, forb production increased $12.33 \mathrm{~kg} \cdot \mathrm{ha}^{-1} \cdot \mathrm{cm}^{-1}$ of $\mathrm{P} 2 \mathrm{M}$ and $0.43 \mathrm{~kg} \cdot \mathrm{ha}^{-1} \cdot{ }^{\circ} \mathrm{C}^{-1}$ of T2M. The light and heavy grazing treatments produced the most forbs and the ungrazed and extreme treatments produced the least (Table 4).
Table 4. Mean grass, forb, shrub, and total production on overflow range sites at mid-grazing season from 1989 to 2005. Grass, forb, and total production means are adjusted for the effects of P2M and T2M.

\begin{tabular}{lcccc}
\hline $\begin{array}{c}\text { Grazing } \\
\text { treatment }\end{array}$ & $\begin{array}{c}\text { Grass } \\
\text { production } \\
\left(\mathrm{kg} \cdot \mathrm{ha}^{-1}\right)\end{array}$ & $\begin{array}{c}\text { Forb } \\
\text { production } \\
\left(\mathrm{kg} \cdot \mathrm{ha}^{-1}\right)\end{array}$ & $\begin{array}{c}\text { Shrub } \\
\text { production } \\
\left(\mathrm{kg} \cdot \mathrm{ha}^{-1}\right)\end{array}$ & $\begin{array}{c}\text { Total } \\
\text { production } \\
\left(\mathrm{kg} \cdot \mathrm{ha}^{-1}\right)\end{array}$ \\
\hline Ungrazed & $2351 \mathrm{a}^{2}$ & $755 \mathrm{c}$ & $464 \mathrm{~b}$ & $3574 \mathrm{~b}$ \\
Light & $2424 \mathrm{a}$ & $1424 \mathrm{a}$ & $381 \mathrm{bc}$ & $4194 \mathrm{a}$ \\
Moderate & $2521 \mathrm{a}$ & $1171 \mathrm{~b}$ & $509 \mathrm{ab}$ & $4172 \mathrm{a}$ \\
Heavy & $2290 \mathrm{a}$ & $1286 \mathrm{ab}$ & $667 \mathrm{a}$ & $4191 \mathrm{a}$ \\
Extreme & $1719 \mathrm{~b}$ & $850 \mathrm{c}$ & $269 \mathrm{c}$ & $2769 \mathrm{C}$ \\
Pooled SE & 102 & 76 & 57 & 134
\end{tabular}

${ }^{1}$ Because grass, forb, shrub, and total are each adjusted separately for the effects of P2M and T2M, grass, forb, and shrub production do not sum to total production.

${ }^{2}$ Means followed by the same letter in the same column are not significantly different at the $P \leq 0.05$ level.

Silty Range Sites. On silty range sites, forb production was not significantly affected by temperature, but it increased $11.29 \mathrm{~kg} \cdot \mathrm{ha}^{-1} \cdot \mathrm{cm}^{-1}$ of $\mathrm{P} 2 \mathrm{M}$. The light, moderate, and heavy grazing treatments produced the most forbs and the ungrazed and extreme treatments produced the least (Table 5).

Shrub Production. Overflow Range Sites. Shrub production at midseason was not significantly affected by either temperature or precipitation. The greatest shrub production was on the heavy grazing treatment and the least was on the extreme grazing treatment, although it was not significantly less than on the light treatment (Table 4).

Total Production. Overflow Range Sites. Total production at mid-grazing season on overflow sites increased $49.40 \mathrm{~kg}$. $\mathrm{ha}^{-1} \cdot \mathrm{cm}^{-1}$ of P2M and $1.16 \mathrm{~kg} \cdot \mathrm{ha}^{-1} \cdot{ }^{\circ} \mathrm{C}^{-1}$ of T2M. There was no significant difference in production between light, heavy, or moderate grazing intensities, but the production on these treatments were all significantly greater than the production on the ungrazed treatment. The ungrazed treatment had greater production than did the extreme treatment (Table 4).

Silty Range Sites. Total production at midseason on silty sites increased $28.52 \mathrm{~kg} \cdot \mathrm{ha}^{-1} \cdot \mathrm{cm}^{-1}$ of P2M and $1.08 \mathrm{~kg} \cdot \mathrm{ha}^{-1}$.

Table 5. Mean grass, forb, and total production on silty range sites at mid-grazing season from 1989 to 2005. Grass and total production means are adjusted for the effects of $\mathrm{P} 2 \mathrm{M}$ and $\mathrm{T} 2 \mathrm{M}$, and forb production means are adjusted for the effect of P2M.

\begin{tabular}{lccc}
\hline $\begin{array}{c}\text { Grazing } \\
\text { treatment }\end{array}$ & $\begin{array}{c}\text { Grass production } \\
\left(\mathrm{kg} \cdot \mathrm{ha}^{-1}\right)\end{array}$ & $\begin{array}{c}\text { Forb production } \\
\left(\mathrm{kg} \cdot \mathrm{ha}^{-1}\right)\end{array}$ & $\begin{array}{c}\text { Total production } \\
\left(\mathrm{kg} \cdot \mathrm{ha}^{-1}\right)\end{array}$ \\
\hline Ungrazed & $2340 \mathrm{~b}^{2}$ & $409 \mathrm{c}$ & $2765 \mathrm{~b}$ \\
Light & $2565 \mathrm{a}$ & $607 \mathrm{ab}$ & $3186 \mathrm{a}$ \\
Moderate & $2177 \mathrm{~b}$ & $683 \mathrm{a}$ & $2888 \mathrm{~b}$ \\
Heavy & $1763 \mathrm{c}$ & $671 \mathrm{a}$ & $2453 \mathrm{C}$ \\
Extreme & $1631 \mathrm{c}$ & $495 \mathrm{bc}$ & $2145 \mathrm{~d}$ \\
Pooled SE & 75 & 45 & 85
\end{tabular}

${ }^{1}$ Because grass, forb, and total are each adjusted separately for the effects of P2M and T2M, grass and forb production do not sum to total production.

${ }^{2}$ Means followed by the same letter in the same column are not significantly different at the $\mathrm{P}$ $\leq 0.05$ level. 
Table 6. Mean grass, forb, and total production on silty range sites at the end of the grazing season from 1989 to 2005. Grass and total production means are adjusted for the effects of $\mathrm{P} 2 \mathrm{E}$ and $\mathrm{T} 2 \mathrm{E}$, and forb production means are adjusted for the effect of P2E.

\begin{tabular}{lccc}
\hline $\begin{array}{c}\text { Grazing } \\
\text { treatment }\end{array}$ & $\begin{array}{c}\text { Grass production } \\
\left(\mathrm{kg} \cdot \mathrm{ha}^{-1}\right)\end{array}$ & $\begin{array}{c}\text { Forb production } \\
\left(\mathrm{kg} \cdot \mathrm{ha}^{-1}\right)\end{array}$ & $\begin{array}{c}\text { Total production } \\
\left(\mathrm{kg} \cdot \mathrm{ha}^{-1}\right)\end{array}$ \\
\hline Ungrazed & $2466 \mathrm{~b}^{2}$ & $387 \mathrm{c}$ & $2865 \mathrm{~b}$ \\
Light & $2771 \mathrm{a}$ & $632 \mathrm{ab}$ & $3410 \mathrm{a}$ \\
Moderate & $2429 \mathrm{~b}$ & $699 \mathrm{a}$ & $3156 \mathrm{a}$ \\
Heavy & $1974 \mathrm{c}$ & $651 \mathrm{ab}$ & $2637 \mathrm{bc}$ \\
Extreme & $1982 \mathrm{c}$ & $510 \mathrm{bc}$ & $2501 \mathrm{c}$ \\
Pooled SE & 90 & 55 & 98
\end{tabular}

${ }^{1}$ Because grass, forb, and total are each adjusted separately for the effects of P2E and T2E, grass and forb production does not sum to total production.

${ }^{2}$ Means followed by the same letter in the same column are not significantly different at the $P \leq 0.05$ level.

${ }^{\circ} \mathrm{C}^{-1}$ of T2M. The light treatment produced the most forage. Production decreased as grazing intensity increased or decreased from that level (Table 5).

\section{Production at End of Grazing Season}

Grass Production. Silty Range Sites. No significant interaction between temperature and grazing treatment was observed in grass production on either range site from emergence to the end of the grazing season. No interaction between precipitation and treatment occurred on silty sites. Grass production from emergence to the end of the grazing season on silty ranges sites increased $20.75 \mathrm{~kg} \cdot \mathrm{ha}^{-1} \cdot \mathrm{cm}^{-1}$ of P2E (defined as the sum of precipitation from the end of the growing season in the previous year to the end of the grazing season in the current year) and $0.35 \mathrm{~kg} \cdot \mathrm{ha}^{-1} \cdot{ }^{\circ} \mathrm{C}^{-1}$ of T2E (defined as the sum of mean daily sod temperature above $0^{\circ} \mathrm{C}$ from when the ground thawed until the end of the grazing season in the current year). The light treatment produced the most forage. Production decreased as grazing intensity increased or decreased from that level, although the heavy and extreme treatments were not significantly different (Table 6).

Overflow Range Sites. On overflow range sites, an interaction between precipitation and grazing intensity for grass production at the end of the grazing season was observed. The ungrazed treatment was not significantly affected by precipitation or temperature, but the other treatments all increased approximately $31.44 \mathrm{~kg} \cdot \mathrm{ha}^{-1} \cdot \mathrm{cm}^{-1}$ of P2E (Fig. 6) and approximately $0.24 \mathrm{~kg} \cdot \mathrm{ha}^{-1} \cdot{ }^{\circ} \mathrm{C}^{-1}$ of T2E. The moderate and light grazing treatments produced the most grass, with production decreasing at higher grazing intensities (Table 7).

Forb Production. Overflow Range Sites. Temperature did not have a significant effect on forb production at the end of the grazing season, and precipitation did not interact with treatment to affect forb production. On overflow range sites, forb production at the end of the grazing season increased $7.75 \mathrm{~kg} \cdot \mathrm{ha}^{-1} \cdot \mathrm{cm}^{-1}$ of P2E. There was no significant difference in forb production between the light, moderate, and heavy treatments, but forb production was significantly lower on the extreme treatment, and the ungrazed treatment

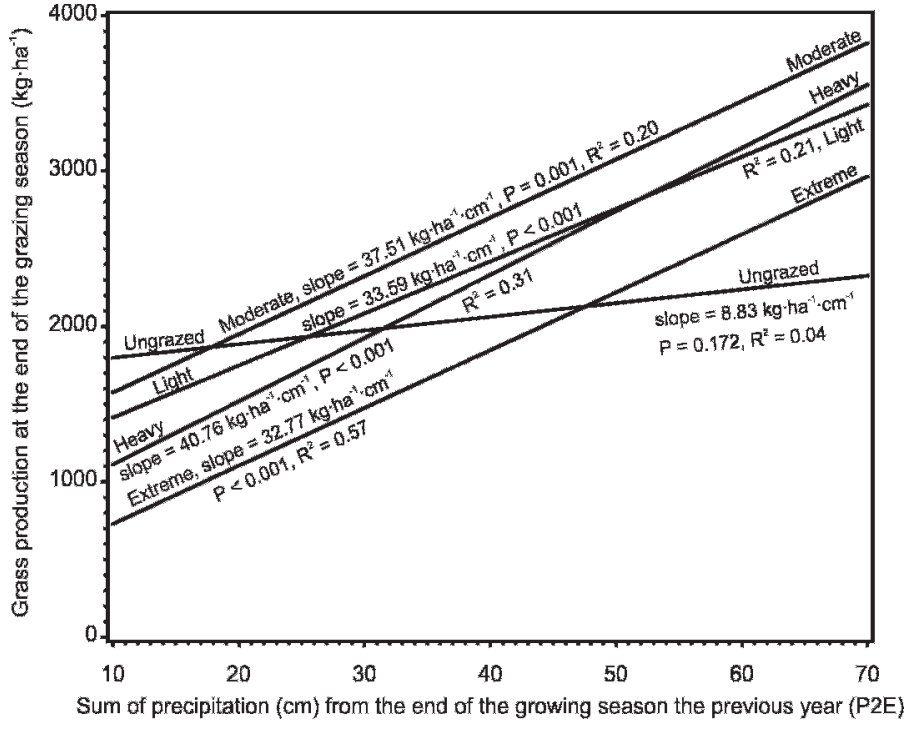

Figure 6. Overflow range site relationship between grass production at the end the grazing season and P2E from 1989 to 2005.

had less forb production than any of the grazed treatments (Table 7).

Silty Range Sites. On silty range sites, forb production at the end of the grazing season increased $7.10 \mathrm{~kg} \cdot \mathrm{ha}^{-1} \cdot \mathrm{cm}^{-1}$ of P2E. There was no significant difference in forb production between the light, moderate, or heavy treatments, but the extreme and ungrazed treatments had lower forb production (Table 6).

Shrub Production. Overflow Range Sites. No interaction occurred between treatment and precipitation or temperature on shrub production on overflow range sites at the end of the grazing season. Shrub production increased $4.23 \mathrm{~kg} \cdot \mathrm{ha}^{-1} \cdot \mathrm{cm}^{-1}$ of P2E and decreased $0.08 \mathrm{~kg} \cdot \mathrm{ha}^{-1}$. ${ }^{\circ} \mathrm{C}^{-1}$ of T2E. The heavy grazing treatment had the most shrub production and the extreme treatment had the least, although it was not significantly less than on the light treatment (Table 7).

Total Production. Silty Range Sites. Total production at the end of the grazing season on silty range sites increased $28.63 \mathrm{~kg} \cdot \mathrm{ha}^{-1} \cdot \mathrm{cm}^{-1}$ of $\mathrm{P} 2 \mathrm{E}$ and increased $0.29 \mathrm{~kg} \cdot$ $\mathrm{ha}^{-1} \cdot{ }^{\circ} \mathrm{C}^{-1}$ of T2E. The light and moderate treatments produced the most forage, with the ungrazed, heavy, and extreme treatments producing significantly less (Table 6).

Overflow Range Sites. On overflow range sites, a significant interaction was observed between precipitation and treatment, affecting total production. Precipitation did not show a significant effect on production on the ungrazed treatment, but production increased $46.85 \mathrm{~kg} \cdot \mathrm{ha}^{-1} \cdot \mathrm{cm}^{-1}\left(R^{2}=0.42\right)$ of P2E on grazed treatments. Slopes on the grazed treatments ranged from $37.63 \mathrm{~kg} \cdot \mathrm{ha}^{-1} \cdot \mathrm{cm}^{-1}\left(R^{2}=0.14\right)$ on the light treatment to $56.35 \mathrm{~kg} \cdot \mathrm{ha}^{-1} \cdot \mathrm{cm}^{-1}\left(R^{2}=0.38\right)$ on the heavy treatment, but they were not significantly different between grazed treatments (Fig. 7). Forage production did not differ significantly between the light, moderate, and heavy treatments, but the extreme treatment produced significantly less forage than did the other grazed treatments (Table 7). 
Table 7. Mean grass, forb, shrub, and total production on overflow range sites at the end of the grazing season from 1989 to 2005. Grass, shrub, and total production means are adjusted for the effects of P2E and T2E; forb production means are adjusted for the effect of P2E.

\begin{tabular}{|c|c|c|c|c|c|c|}
\hline \multirow[b]{2}{*}{$\begin{array}{l}\text { Grazing } \\
\text { treatment }\end{array}$} & \multicolumn{2}{|c|}{ Grass production } & \multirow[b]{2}{*}{$\begin{array}{l}\text { Forb production } \\
\left(\mathrm{kg} \cdot \mathrm{ha}^{-1}\right)\end{array}$} & \multirow[b]{2}{*}{$\begin{array}{l}\text { Shrub production } \\
\qquad\left(\mathrm{kg} \cdot \mathrm{ha}^{-1}\right)\end{array}$} & \multicolumn{2}{|c|}{ Total production } \\
\hline & $\begin{array}{l}\text { Grass production } \\
\left(\mathrm{kg} \cdot \mathrm{ha}^{-1}\right)\end{array}$ & $\begin{array}{l}\text { Greater than ungrazed } \\
\text { if } \mathrm{P} 2 \mathrm{E} \text { greater than }\end{array}$ & & & $\begin{array}{l}\text { Total production } \\
\left(\mathrm{kg} \cdot \mathrm{ha}^{-1}\right)\end{array}$ & $\begin{array}{c}\text { Greater than ungrazed if } \mathrm{P} 2 \mathrm{E} \\
\text { greater than }\end{array}$ \\
\hline Ungrazed & - & - & $575 c^{4}$ & $387 \mathrm{~b}$ & - & - \\
\hline Light & $2556 a b$ & 38.21 & $1283 \mathrm{a}$ & $285 \mathrm{bc}$ & $4131 \mathrm{a}$ & 26.70 \\
\hline Moderate & $2861 \mathrm{a}$ & 32.36 & $1152 \mathrm{a}$ & $356 \mathrm{~b}$ & $4360 \mathrm{a}$ & 24.84 \\
\hline Heavy & $2510 b$ & 40.41 & $1259 \mathrm{a}$ & 556 a & $4362 \mathrm{a}$ & 26.24 \\
\hline Extreme & $1982 \mathrm{C}$ & - & $902 \mathrm{~b}$ & $155 \mathrm{c}$ & $3087 b^{5}$ & 53.15 \\
\hline Pooled SE & 115 & & 80 & 49 & 137 & \\
\hline
\end{tabular}

${ }^{1}$ Production was greater on the treatment than on the ungrazed treatment if P2E was greater than the given value; otherwise, they are not significantly different $(P=0.05)$.

${ }^{2}$ Because grass, forb, shrub, and total are each adjusted separately for the effects of P2E and/or P2E and T2E, grass, forb, and shrub production does not sum to total production.

${ }^{3}$ Production was greater on the treatment than on the ungrazed treatment if $\mathrm{P} 2 \mathrm{E}$ was greater than the given value; otherwise, they were not significantly different $(P=0.05)$.

${ }^{4}$ Means followed by the same letter in the same column are not significantly different at the $P \leq 0.05$ level.

${ }^{5}$ Production was less on extreme than on ungrazed if P2E was less than 31.52 ; between 31.52 and 53.15 , they were not significantly different $(P=0.05)$.

\section{DISCUSSION}

Rangeland is classified into range sites because of differences in productivity due to soils and topography and, consequently, differences in nutrients and available water (Dykesterhuis 1949; Cook and Stubbendieck 1986). The interaction of range site and grazing intensity on forage production is likely due to the amount of vegetation and litter and their effects on soil temperature and water infiltration or evaporation (Weaver and Rowland 1952; Lodge et al. 2001).

In our study it is interesting that at the beginning of the grazing season, grass production on overflow range sites responded differently to temperature depending on the grazing treatment. However, grass production had the same response to precipitation on all treatments. On silty range sites we found the converse to be true: grass production responded the same to temperature on all treatments, but it responded differently to precipitation depending on the treatment.

On overflow range sites, available soil water has tended to be less on the sites that were most heavily grazed (Patton and Nyren 1998). On silty range sites, the moderately grazed

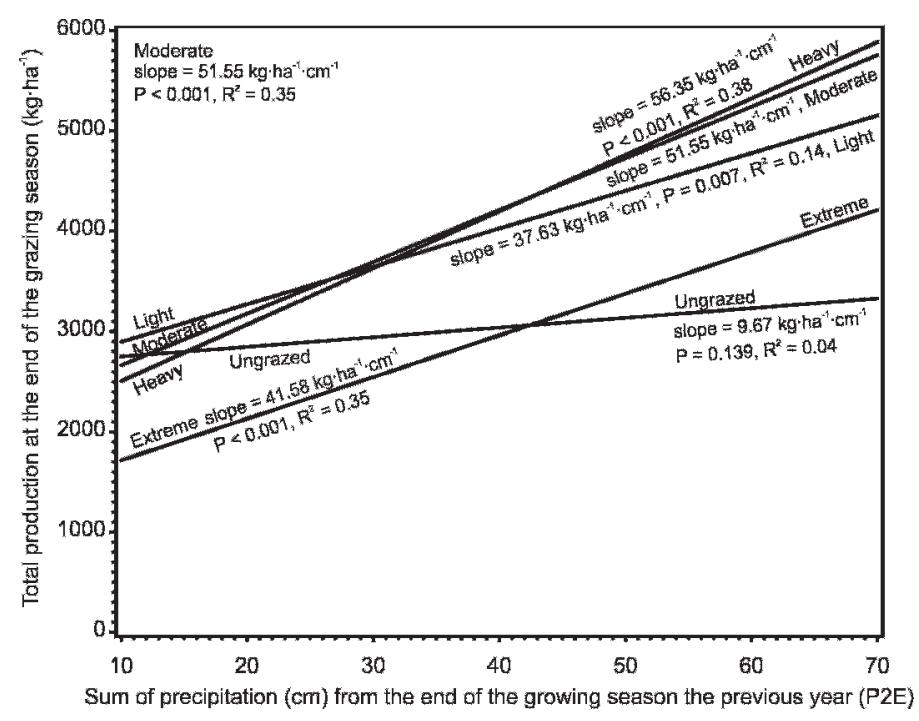

Figure 7. Overflow range site relationship between total production at the end of the grazing season and P2E from 1989 to 2005. treatments tended to have more available soil water than ungrazed or extremely grazed treatments. Significant differences between treatments $(P \leq 0.05)$ have occurred during periods of soil-water recharge and discharge, indicating that increased runoff and evaporation occurs from the soil surface on the heavily grazed treatments. Plants on the ungrazed treatment on silty sites had more leaf area than plants on the moderate treatment and appear to remove more water through transpiration.

Moisture is more limited on the silty range sites than on the overflow sites, but the ungrazed and light grazing treatments may be able to hold more water in wetter springs because of their greater residual cover, thus allowing these treatments to produce more in wetter years (Lodge et al. 2001).

Generally, the removal of above-ground biomass through grazing is stressful to individual plants (Crider 1955), so grass production would tend to decrease with increased grazing intensity. However, this trend is modified by the interactive effect of residual plant material on soil temperature and available water (Weaver and Rowland 1952).

The thinning of the grass stand through grazing provides openings for spring forb growth, so forb production on both silty and overflow range sites tended to increase with grazing intensity early in the growing season. The response of forbs to precipitation was much less than that of grasses, with the exception of the moderate, heavy, and extreme treatments on silty sites at the beginning of the grazing season. Grasses and forbs have very different growth forms, with grasses possessing traits that aid drought tolerance, such as basal meristems, narrow, vertically oriented leaves, and relatively shallow and fibrous root systems. This would make grasses more reliant on water in the upper layer of the soil profile. Forbs have great diversity in leaf and meristem architecture. Many forbs have deeper root systems than grasses, allowing them to access deeper, less variable water supplies. However, Fay et al. (2002) found the forb Canada goldenrod (Solidago canadensis L.) to be more responsive to soil water in the 0 to $30 \mathrm{~cm}$ layer than the dominant warm season grass big bluestem (Andropogon gerardii Vitman). These researchers felt that the unresponsiveness of big bluestem may have resulted from its inherently high water use efficiency and drought tolerance mechanisms, which can buffer plant performance from soil water variability. The grassland in 
our study is dominated by Kentucky bluegrass, which is a coolseason species. Its roots may extend to depths of 1.5-2.1 m, but they predominate in the top few centimeters. This grass begins growth as soon as the surface temperature exceeds $0^{\circ} \mathrm{C}$ as long as water is available, but it ceases growth and turns brown during dry periods, quickly reviving again following rain (Weaver 1926). The responses in this study were more consistent with the common views of soil resource partitioning between shallow rooted grasses and deep rooted forbs than with the responses observed by Fay et al. (2002). Because grasses dominate these sites, the treatment effect for total production showed a similar trend to that for grass production.

By midseason, grass growth on ungrazed overflow range sites had made up for its slower initial growth. Grass growth on the extreme treatment had lost any advantage it had gained in years with a warmer spring or later initiation of grazing, and no significant interaction between precipitation or temperature and grazing intensity was observed. Only the extreme treatment produced significantly less grass than the other treatments.

By midseason, on the silty range sites, grass production was no longer affected by an interaction between precipitation and grazing intensity. The light grazing intensity was most productive at this point and the extreme and heavy intensities were the least productive.

At the beginning of the grazing season, forb production was greatest on the extreme treatment and decreased with decreasing grazing intensity, but by midseason, light grazing was the most productive treatment on overflow range sites, and moderate grazing was the most productive treatment on silty range sites, with production decreasing with higher or lower grazing intensities. The ungrazed treatments produced the smallest amount of forbs on both silty and overflow sites, although forb production on the extreme treatment was not significantly greater. Production of forbs on ungrazed treatment is probably reduced by competition with grasses, and forbs on the extreme grazing treatment are probably weakened by cattle grazing.

On silty range sites at midseason, total production had essentially the same response to grazing intensity as grass production. On overflow range sites, production was similar, but the ungrazed treatment had significantly less production than all the grazed treatments except for the extreme treatment.

Grass, forb, and total production on silty range sites at the end of the grazing season responded to grazing intensity in the same patterns as were established at the middle of the grazing season. At the end of the season, the grazed treatments on overflow range sites also had the same patterns of grass, forb, shrub, and total production as were established at the middle of the grazing season, but the ungrazed treatment at this point did not show a significant response in production to either precipitation or temperature within the range of values experienced. The litter layer on the ungrazed treatment acts as an impediment to the movement of water either into or out of the soil (Weaver and Rowland 1952). The layer may be thinner in dry years, allowing more water to move into the soil, and thicker after wet years, restricting water movement into the soil and thus moderating the effect that precipitation has on production.

While most studies in the Great Plains and more arid regions report a positive relationship between precipitation and forage production (Smoliak 1986; Sala et al. 1988; Lauenroth and
Sala 1992), a relationship between temperature and production is less commonly reported. Lauenroth and Sala (1992), using average annual air temperature, found no relationship between temperature and forage production. Smoliak (1986) found a negative correlation between June and May average monthly air temperatures and production. In this case higher temperatures may cause more evaporation, reducing the positive effect of precipitation. Accumulated average daily sod temperature above $0^{\circ} \mathrm{C}$ reflects the length of time that plants have had suitable conditions for growth, and thus maybe time as much as temperature has a positive affect on forage production.

Our measurements of precipitation and temperature are rather crude in that they don't consider the timing of precipitation events or fluctuations in temperature. Plants respond to available water in the soil when temperatures are suitable for growth, and precipitation received late in the growth period does not make up for the lack of water during the period of most active growth. More of the variation in our data may be explained by looking at the effects of precipitation and temperature from shorter periods of time or applying a simulation model, e.g., ERHYM (Wight and Neff 1983); SPUR (Hanson et al. 1992).

\section{MANAGEMENT IMPLICATIONS}

We conclude from observing 17 years of grazing at five levels of intensity on two range sites that herbivores can induce a nonlinear or biphasic growth response in the plant community, where low levels of herbivory increase production and high levels of herbivory reduce production. This provides evidence in support of the grazing optimization hypothesis advanced by Dyer et al. (1993), McNaughton (1993), and NoyMeir (1993): that production is highest at some intermediate level of grazing. Milchunas et al. (1994), in a similar long-term grazing intensity experiment on short-grass prairie in northcentral Colorado, found that the ungrazed treatment was the most productive and that production decreased with grazing intensity. The reviews of Belsky (1986) and Painter and Belsky (1993) found no evidence that herbivory benefits grazed plants. We do not dispute these conclusions but speculate that the reduced production found on the ungrazed treatment in our study is a result of the inhibiting effect that litter buildup has on plant growth. Earlier results from our study (Biondini et al. 1998) did not report lower production on the ungrazed treatment, underscoring the importance of long-term studies in ecological research.

It is difficult to predict what stocking rate would result in the maximum biomass, and indeed that rate varies annually due to weather. But it is clear that in south-central North Dakota, moderate grazing can maintain a higher level of herbage production as compared to complete rest or overgrazing on this Kentucky bluegrass-dominated rangeland.

\section{LITERATURE CITED}

Angell, R. F., R. F. MılleR, and M. R. Haferkamp. 1990. Variability of crude protein in crested wheatgrass at defined stages of phenology. Journal of Range Management 43:186-189. 
Belsky, A. J. 1986. Does herbivory benefit plants? A review of the evidence. American Naturalist 127:870-892.

Biondinl, M. E., B. D. Patton, and P. E. Nyren. 1998. Grazing intensity and ecosystem processes in a northern mixed-grass prairie, USA. Ecological Applications 8:469-479.

Cook, C. W., and J. StubBendieCk [EDS.]. 1986. Range research: basic problems and techniques. Denver, C0: Society for Range Management. 317 p.

CRIDER, F. J. 1955. Root-growth stoppage resulting from defoliation of grass. USDA Tech. Bull. 1102. Washington, DC: USDA.

Dyer, M. I., C. L. Turner, and T. R. Seastedt. 1993. Herbivory and its consequences. Ecological Applications 3:10-16.

Dykesterhuis, E. J. 1949. Condition and management of range land based on quantitative ecology. Journal of Range Management 2:104-115.

ENz, J. W. 2006. NDAWN-North Dakota Agricultural Weather Network. Available at: http://www.ndawn.ndsu.nodak.edu/index.html. Accessed 7 September 2006.

Fay, P. A., J. D. Carlisle, B. T. Danner, M. S. Lett, J. K. McCarron, C. Stewart, A. K. Knapp, J. M. BlaiR, And S. L. Collins. 2002. Altered rainfall patterns, gas exchange, and growth in grasses and forbs. Journal of Plant Science 163:549-557.

Frank, A. B., And R. E. Ries. 1990. Effect of soil water, nitrogen, and growing degree-days on morphological development of crested and western wheatgrass. Journal of Range Management 43:257-260.

Ganskopp, D. 1998. Thurber needlegrass: seasonal defoliation effects on forage quantity and quality. Journal of Range Management 51:276-281.

Hanson, J. D., B. B. Baker, and R. D. Bourdon. 1992. SPUR2: Documentation and user guide. GPSR Tech. Rep. 1. Washington, DC: USDA-ARS. 24 p.

HUITEMA, B. E. 1980. The analysis of covariance and alternatives. New York: John Wiley \& Sons. $445 p$.

JefFERIES, R. L. 1988. Vegetational mosaics, plant-animal interactions, and resources for plant growth. In: L. D. Gottlieb and S. K. Jain [EDS.]. Plant evolutionary biology. London, UK: Chapman and Hall. p. 341-369.

Lauenroth, W. K., and O. E. Sala. 1992. Long-term forage production of North American shortgrass steppe. Ecological Applications 2:397-403.

Lodge, G. M., S. R. Murphy, And I. R. Johnson. 2001. Soil water balance modelling highlights limitations for pasture production in northern NSW. Proceedings of the 10th Australian Agronomy Conference; 29 January-1 February 2001. Hobart, Australia: Australian Society of Agronomy. Available at: http://www. regional.org.au/au/asa/2001/2/b/lodge.htm. Accessed 12 December 2006.
McNaughton, S. J. 1993. Grasses and grazers, science and management. Ecological Applications 3:17-20.

Milchunas, D. G., J. R. Forwood, and W. K. Lauenroth. 1994. Productivity of longterm grazing treatments in response to seasonal precipitation. Journal of Range Management 47:133-139.

NoY-Meir, I. 1993. Compensating growth of grazed plants and its relevance to the use of rangelands. Ecological Applications 3:32-34.

Painter, E. L., And A. J. Belsky. 1993. Application of herbivore optimization theory to rangelands of the western United States. Ecological Applications 3:2-9.

Patton, B. D., and P. E. Nyren. 1998. The effect of grazing intensity on soil water and rangeland productivity in south-central North Dakota. In: D. F. Potts [ED.]. Proceedings of AWRA Specialty Conference, Rangeland Management and Water Resources, 27-29 May 1998. Herndon, VA: American Water Resources Association. p. 219-228.

Sala, O. E., W. J. Parton, L. A. Joyce, and W. K. Lauenroth. 1988. Primary production of the central grassland region of the United States. Ecology 69:40-45.

SmolıK, S. 1986. Influence of climatic conditions on production of StipaBouteloua prairie over a 50-year period. Journal of Range Management 39:100-103.

StebBins, G. L. 1981. Coevolution of grasses and herbivores. Annals of the Missouri Botanical Garden 68:75-86.

USDA, NRCS. 2006. The PLANTS database. Baton Rouge, LA: National Plant Data Center. Available at: http://plants.usda.gov. Accessed 7 September 2006.

WALKER, J. W. 1995. Viewpoint: grazing management and research now and in the next millennium. Journal of Range Management 48:350-357.

Wang, J. U. 1960. A critique of the head unit approach to plant response studies. Ecology 41:785-790.

Weaver, J. E. 1926. Root development of field crops. New York, NY: McGraw-Hill. 297 p. Available at: http://www.soilandhealth.org/01aglibrary/010139fieldcroproots/010139toc.html. Accessed 1 December 2006.

Weaver, J. E., and N. W. Rowland. 1952. Effects of excessive natural mulch on development, yield, and structure of native grassland. Botanical Gazette 114:1-19.

Wight, J. R., And Neff E. L. 1983. Soil-vegetation-hydrology studies, Volume II. A user manual for ERHYM the EKALAKA rangeland hydrology and yield model, ARR-W-29. Washington, DC: USDA-ARS, Agricultural Research Results. 38 p. 